\title{
Purification, characterization and amino acid content of cholesterol oxidase produced by Streptomyces aegyptia NEAE 102
}

Noura El-Ahmady El-Naggar ${ }^{1 *}$, Sahar F. Deraz ${ }^{2}$, Hoda M. Soliman ${ }^{3}$, Nehal M. El-Deeb ${ }^{4}$ and Nancy M. El-Shweihy ${ }^{1}$

\begin{abstract}
Background: There is an increasing demand on cholesterol oxidase for its various industrial and clinical applications. The current research was focused on extracellular cholesterol oxidase production under submerged fermentation by a local isolate previously identified as Streptomyces aegyptia NEAE 102. The crude enzyme extract was purified by two purification steps, protein precipitation using ammonium sulfate followed by ion exchange chromatography using DEAE Sepharose CL-6B. The kinetic parameters of purified cholesterol oxidase from Streptomyces aegyptia NEAE 102 were studied.

Results: The best conditions for maximum cholesterol oxidase activity were found to be 105 min of incubation time, an initial $\mathrm{pH}$ of 7 and temperature of $37^{\circ} \mathrm{C}$. The optimum substrate concentration was found to be $0.4 \mathrm{mM}$. The higher thermal stability behavior of cholesterol oxidase was at $50{ }^{\circ} \mathrm{C}$. Around $63.86 \%$ of the initial activity was retained by the enzyme after 20 min of incubation at $50{ }^{\circ} \mathrm{C}$. The apparent molecular weight of the purified enzyme as sized by sodium dodecyl sulphate-polyacryalamide gel electrophoresis was approximately $46 \mathrm{KDa}$. On DEAE Sepharose CL-6B column cholesterol oxidase was purified to homogeneity with final specific activity of $16.08 \mathrm{U} / \mathrm{mg}$ protein and 3.14-fold enhancement. The amino acid analysis of the purified enzyme produced by Streptomyces aegyptia NEAE 102 illustrated that, cholesterol oxidase is composed of 361 residues with glutamic acid as the most represented amino acid with concentration of $11.49 \mu \mathrm{g} / \mathrm{mL}$.
\end{abstract}

Conclusions: Taking into account the extracellular production, wide pH tolerance, thermal stability and shelf life, cholesterol oxidase produced by Streptomyces aegyptia NEAE 102 suggested that the enzyme could be industrially useful.

Keywords: Streptomyces aegyptia NEAE 102, Cholesterol oxidase, Purification, DEAE Sepharose CL-6B, Characterization, Molecular weight, Amino acid contents

\section{Background}

Cholesterol oxidase (EC 1.1.3.6) or 3ß-hydroxysteroid oxidase is a FAD (flavin adenine dinucleotide)-dependent enzyme belongs to the family of oxidoreductases, which is capable of catalyzing two reactions, oxidation and isomerization of cholesterol to give rise ketones (cholestenone) using molecular oxygen as an electron acceptor to form cholest-4-en-3-one and hydrogen peroxide [1].

\footnotetext{
* Correspondence: nouraelahmady@yahoo.com

'Department of Bioprocess Development, Genetic Engineering and

Biotechnology Research Institute, City of Scientific Research and

Technological Applications, Alexandria, Egypt

Full list of author information is available at the end of the article
}

Now cholesterol oxidase has considered as one of the most widely used enzymes in clinical laboratories as it participates in bile acid biosynthesis. The cholesterol oxidase enzyme exhibit many distinct properties; it is simple, specific and highly sensitive; its clinical applications has become widespread in the determination of serum cholesterol for the assessment of atherosclerosis, coronary heart disease and other lipid disorders and for determining the risk of heart attack and thrombosis. This enzyme shows biological insecticidal activity and it has been developed as a pest control in the agricultural industry especially in transgenic crops and as a potent 
parricide $[2,3]$. Cholesterol oxidases can also be used to produce a precursor for chemical synthesis of steroid hormones [1] and to degrade of dietary cholesterol in foods [4].

The cholesterol oxidases are classified into two types (I and II) on the basis of the nature of the FAD linkages to the enzyme protein molecules. The type I and II involve non-covalent and covalent linkage of the FAD cofactors to the protein molecules, respectively [5]. The type I enzyme belongs to the glucose/methanol/choline (GMC) oxidoreductase family, while the type II enzyme belongs to the vanillyl alcohol oxidase (VAO) family [5]. Type I enzymes have been identified mostly in actinomycetes such as, Streptomyces sp. SA-COO, Rhodococcus equi, Mycobacterium tuberculosis, Corynebacterium urealyticum [6]. Although cholesterol oxidases of both classes share the same catalytic activity, they show significant differences in their redox and kinetic properties. In general, to exhibit a broad range of steroid specificities and capability of oxidizing a number of hydroxysterols, the presence of a $3 \beta$-hydroxyl group is an important requirement for their activity in all cases [7].

Cholesterol oxidases have been purified and characterized from several microorganisms belongs to diverse environments and their action is strongly influenced by the environment of its substrate [8]. According to Whitaker [9] the purified enzyme was characterized by determining the optimum $\mathrm{pH}$ and temperature for both activity and stability. The molecular weights of the cholesterol oxidases have been reported in the range of $36-61 \mathrm{kDa}$. Microbial cholesterol oxidases generally have neutral $\mathrm{pH}$ optima and possess stability over a wide range $[10,11]$.

The objective of this study is to purify and characterize the cholesterol oxidase produced in the fermentation medium of Streptomyces aegyptia NEAE 102.

\section{Methods}

Microorganisms and cultural conditions

Streptomyces aegyptia NEAE 102 [12] and other Streptomyces spp. used in this study are local isolates isolated from various soil samples which collected from different localities of Egypt and kindly provided by Dr. Noura El-Ahmady El-Naggar (Department of Bioprocess Development, Genetic Engineering and Biotechnology Research Institute, City of Scientific Research and Technological Applications, Alexandria, Egypt). These isolates were maintained on slopes containing starch-nitrate agar medium [13] of the following composition (g/L): Starch 20; $\mathrm{KNO}_{3} 2 ; \mathrm{K}_{2} \mathrm{HPO}_{4}$ 1; $\mathrm{MgSO}_{4} .7 \mathrm{H}_{2} \mathrm{O}$ 0.5; $\mathrm{NaCl} 0.5 ; \mathrm{CaCO}_{3} 3 ; \mathrm{FeSO}_{4} .7 \mathrm{H}_{2} \mathrm{O}$ 0.01; agar 20 and distilled water up to $1 \mathrm{~L}$. Slopes were incubated for a period of 7 days at $30{ }^{\circ} \mathrm{C}$. The isolates were stored as spore suspensions in $20 \%(\mathrm{v} / \mathrm{v})$ glycerol at $-20{ }^{\circ} \mathrm{C}$ for subsequent investigation.
Qualitative screening for cholesterol oxidase producing microorganisms using colony staining method The principal of cholesterol oxidase activity is based on its ablitiy to convert cholesterol into cholest-4-en-3-one and hydrogen peroxide. Primary screening agar plate containing cholesterol as the sole carbon source was used. This experimental medium contained $(\mathrm{g} / \mathrm{L})$ : Cholesterol 2, $\mathrm{KNO}_{3} 2$, $\mathrm{K}_{2} \mathrm{HPO}_{4} \quad 1, \quad \mathrm{MgSO}_{4} .7 \mathrm{H}_{2} \mathrm{O} \quad 0.5, \mathrm{NaCl} 0.5, \mathrm{CaCO}_{3} 3$, $\mathrm{FeSO}_{4} \cdot 7 \mathrm{H}_{2} \mathrm{O}$ 0.01, agar 20 and distilled water up to $1 \mathrm{~L}$. Agar plates were seeded with spores of actinomycetes and incubated at $30{ }^{\circ} \mathrm{C}$ for a week. To confirm potentialities for cholesterol oxidase production, colony staining method was performed on the grown colonies. Filter paper discs were dipped into the assay solution containing $0.5 \%$ cholesterol; 6\% phenol; 1.7\% 4-aminoantipyrine and 3000U/l horseradish peroxidase in $100 \mathrm{mM}$ potassium phosphate buffer $\mathrm{pH} 7.0$ and were located on grown colonies on the plates and incubated for $24 \mathrm{~h}$ at room temperature. Penetration of cholesterol into the bacterial cell led to development of pink color in the medium surrounding the tested colonies due to the conversion of cholesterol into hydrogen peroxide and formation of quinoneimine dye as a result of cholesterol oxidase activity [14]. The strain which showed the most promising result was selected for further experiments.

\section{Inoculum preparation}

The isolate was grown in $250 \mathrm{~mL}$ Erlenmeyer flasks containing $100 \mathrm{~mL}$ of broth medium consisted of $(\mathrm{g} / \mathrm{L}$ : glucose 12; starch 9; yeast extract 6; peptone 4; $\left(\mathrm{NH}_{4}\right)_{2} \mathrm{SO}_{4} 7.5$; cholesterol 2; $\mathrm{K}_{2} \mathrm{HPO}_{4} 1 ; \mathrm{MgSO}_{4} \cdot 7 \mathrm{H}_{2} \mathrm{O} 0.5 ; \mathrm{FeSO}_{4} \cdot 7 \mathrm{H}_{2} \mathrm{O}$ 0.02; $\mathrm{NaCl} 1 ; \mathrm{MnSO}_{4}$ 0.008; $\mathrm{CaSO}_{4}$ 0.002; $\mathrm{ZnSO}_{4}$ 0.002; $\mathrm{CaCl}_{2}$ 0.0002; Tween 80 0.05) [15]. Five disks of $9 \mathrm{~mm}$ diameter taken from the 7 days old stock culture grown on starch nitrate agar medium were used to inoculate the broth medium and grown at $30{ }^{\circ} \mathrm{C}$ with shaking (200 rpm) for $48 \mathrm{~h}$ and used as inoculum for subsequent experiments.

\section{Production of cholesterol oxidase by submerged fermentation}

The previously prepared inoculums of the selected strain inoculated into $100 \mathrm{~mL}$ of fermentation medium dispensed in $250 \mathrm{~mL}$ Erlenmeyer conical flasks. The inoculated flasks were incubated on a rotatory incubator shaker at $150 \mathrm{rpm}$ and $37^{\circ} \mathrm{C}$. After the specified incubation time for each set of experimental trials, the mycelium of each isolate was centrifuged with cooling $\left(4{ }^{\circ} \mathrm{C}\right)$ at $5000 \times \mathrm{g}$ for $30 \mathrm{~min}$. The cell free supernatant served as crude enzyme and was used for further investigations.

\section{Assessment of enzyme activity}

Cholesterol oxidase activity of isolated bacteria was spectrophotometry determined by the modified method of Sasaki et al. [16] which based on generation of hydrogen peroxide during cholesterol oxidation reaction. This 
reaction was initialized by coupling hydrogen peroxide with 4-aminoantipyrine and phenol to produce quinoneimine dye followed by the measurement of absorption at $500 \mathrm{~nm}$. The reaction mixture was composed of $3 \mu \mathrm{M}$ of cholesterol in $1 \mathrm{~mL}$ of $1 \%$ Triton X-100 (used as substrate of the reaction), $0.1 \mathrm{~mL}$ of enzyme solution, $300 \mu \mathrm{M}$ of potassium phosphate buffer $\mathrm{pH} 7.0,1.2 \mu \mathrm{M}$ 4-aminoantipyrine, $21 \mu \mathrm{M}$ of phenol and $20 \mathrm{U}$ of horseradish peroxidase in a final volume of $3 \mathrm{~mL}$. The enzyme reaction was performed at $37{ }^{\circ} \mathrm{C}$ for 10 min with shaking along incubation period. To stop the reaction, the assay mixture was boiled for $3 \mathrm{~min}$. One unit of enzymatic activity $(\mathrm{U})$ : was defined as the amount of enzyme required to form one micromole of $\mathrm{H}_{2} \mathrm{O}_{2}$ per minute at $37^{\circ} \mathrm{C}$.

\section{Purification of cholesterol oxidase from Streptomyces aegyptia NEAE 102}

The purification was carried out using culture supernatant obtained after centrifugation at $11,000 \times \mathrm{g}$ for $30 \mathrm{~min}$ and used as crude enzyme extract. All purification procedures was performed at $4{ }^{\circ} \mathrm{C}$. The supernatant was transferred into a conical flask, placed on the magnetic stirrer and subjected to ammonium sulphate precipitation by adding finely powdered ammonium sulphate pinch by pinch until complete dissolving and reaching 50\% saturation and kept overnight in the refrigerator. The precipitate was then recovered by centrifugation at $11,000 \times \mathrm{g}$ for $30 \mathrm{~min}$ and the supernatant was further saturated up to $60-90 \%$ with ammonium sulphate. Then the precipitates were collected separately by centrifugation and dissolved in $100 \mathrm{mM}$ potassium phosphate buffer ( $\mathrm{pH}$ 7.0). The dissolved precipitated proteins were dialysed against the same buffer using a pre-treated dialysis tube (SERVA pro, 44144). Precipitate formed during dialysis was removed by centrifugation and was discarded. After dialysis, the samples were subjected to protein content estimation [17] and cholesterol oxidase activity determination. Active cholesterol oxidase fractions were pooled and stored at $4{ }^{\circ} \mathrm{C}$ for further purification. The concentrated enzyme solution was loaded on the column of DEAE-Sepharose CL-6B that was pre-equilibrated with $100 \mathrm{mM}$ potassium phosphate buffer $(\mathrm{pH} 7.0)$ and the column was washed with the same buffer. The bound proteins were eluted with the same buffer containing $0.5 \mathrm{M}$ of $\mathrm{NaCl}$ at a flow rate of $10 \mathrm{~mL}$ per $1 \mathrm{~h}$. All chromatographic runs were monitored for protein estimation by reading the absorption at $280 \mathrm{~nm}$. After fractions dialysis, the protein concentration was determined [17] and cholesterol oxidase activity was assayed. Fractions showing high cholesterol oxidase activity were collected for further use.

\section{Characterization of cholesterol oxidase enzyme}

The effect of the incubation time on cholesterol oxidase activity was studied by incubating the reaction mixture for different times $(15,30,45,60,75,90,105$ and $120 \mathrm{~min})$ and activity was quantified at different time intervals. To define the most functional $\mathrm{pH}$ of cholesterol oxidase activity; the purified enzyme was pre-incubated with different buffers over a range of $\mathrm{pH} 4-10$ under assay conditions, and the residual activities of the enzyme was determined. The buffers, citric acid- $\mathrm{Na}_{2} \mathrm{HPO}_{4}(\mathrm{pH} 4-6), 100 \mathrm{mM}$ potassium phosphate $(\mathrm{pH} 7)$, Tris- $\mathrm{HCl} 0.05 \mathrm{M}(\mathrm{pH}$ 8) and glycine- $\mathrm{NaOH}$ ( $\mathrm{pH} 9-10)$ were used. The influence of temperature on cholesterol oxidase activity was analysed by incubating the assay mixture over the temperature range of $25-60{ }^{\circ} \mathrm{C}$ in potassium phosphate buffer (100 $\mathrm{mM}, \mathrm{pH}$ 7). Effect of different substrate concentration on cholesterol oxidase activity was measured by incubating the enzyme with various concentrations of the specific substrate $(0.05-5 \mathrm{mM})$ and then the enzyme activity was determined at each concentration.

\section{Determination of kinetic properties $\left(\mathrm{K}_{\mathrm{m}}, \mathrm{V}_{\max }\right)$}

The reaction kinetics parameters of the purified enzyme was assayed by linear regression from Lineweaver-Burk plots $[18,19]$ with cholesterol as substrate under assay conditions. The Michaelis-Menten constant $\left(\mathrm{K}_{\mathrm{m}}\right)$ and maximal velocity $\left(\mathrm{V}_{\max }\right)$ were determined for the enzyme as function of temperatures using the Michaelis-Menten equation:

$$
V=\frac{V_{\max }[S]}{K_{m}+[S]}
$$

where $\mathrm{V}$ is the reaction velocity (a function of enzyme concentration), $\mathrm{S}$ is the concentration of the substrate, $\mathrm{K}_{\mathrm{m}}$ is the substrate concentration at half-maximal reaction velocity, and $V_{\max }$ is the maximal velocity. $V_{\max }$ and $K_{m}$ values were determined using nonlinear regression [19].

\section{Enzyme thermal stability}

Thermostability of the cholesterol oxidase was carried by pre-incubating the buffered enzyme prepared in absence of its substrate for different time interval ranging from 0.0 to $90 \mathrm{~min}$ at various temperatures $(50,60,70$ and $80{ }^{\circ} \mathrm{C}$ ). After incubation, the enzyme was cooled then the residual enzyme activities were determined under the defined conditions.

\section{Enzyme pH stability}

The $\mathrm{pH}$ stability of the cholesterol oxidase was assayed after pre-incubating the enzyme in absence of substrate at $4{ }^{\circ} \mathrm{C}$ for $24 \mathrm{~h}$ at $3 \mathrm{~h}$ intervals in buffers of various $\mathrm{pH}$ values ( $\mathrm{pH} 5,7$ and 10). The residual activity was assayed under the standard conditions. 
Polyacrylamide gel electrophoresis indicates a molecular mass of the purified cholesterol oxidase

To size and to determine the enzyme purity, SDS-PAGE (sodium dodecyl sulfate-polyacrylamide gel electrophoresis) was performed as described by Laemmli [20]. The gel system contained a separating acrylamide gel of $10 \%$ and stacking gel $5 \%$ with $0.1 \%$ SDS. After the electrophoresis, the gel was carefully removed from the glass plates and the proteins in the gel were stained in coomassie brilliant blue R-250 followed by distaining with a solution of methanol- acetic acid and water in the ratio of 4:1:5. The molecular mass of individual enzymes was determined by referring to wide range molecular weight protein marker (molecular mass range: 9-178 kDa).

\section{Determination of amino acids content}

Amino acid content of the purified cholesterol oxidase was carried out with Sykam amino acid analyzer at the Central Laboratory, City of Scientific Research and Technological Applications, Alexandria, Egypt. Two mL of the purified enzyme was hydrolyzed in $6 \mathrm{~N} \mathrm{HCl}$ at $110{ }^{\circ} \mathrm{C}$ for about $8-12 \mathrm{~h}$. After removal of hydrochloric acid at $40-60{ }^{\circ} \mathrm{C}$, the hydrolysate was dissolved in $1 \mathrm{~mL}$ water and dried three consecutive times to remove most of the $\mathrm{HCl}$. The hydrolysate was dissolved in sample dilution buffer and was loaded into the cation separation column (LCA K06/Na, $4.6 \times 150$ mm; Sykam GmbH, Eresing, Germany) and analyzed with the Sykam amino acid analyzer. Free amino acids were determined using an ammonia filtration column (LCA, K04/Na, $4.6 \times$ $100 \mathrm{~mm}$, Sykam, GmbH, Eresing, Germany) equipped with an automatic amino acid analyzer (Sykam).

\section{Results and discussion}

Different actinomycete strains were screened for their cholesterol oxidase activity using plate method, formation of pink zones around the colonies indicated the presence of cholesterol oxidase activity (Fig. 1). The promising isolate, Streptomyces aegyptia NEAE 102 was selected for further studies.

\section{Purification of cholesterol oxidase from Streptomyces aegyptia NEAE 102}

The crude culture filtrate of Streptomyces aegyptia NEAE 102 had a total activity of $19527.53 \mathrm{U}$ with protein content $3811.27 \mathrm{mg}$; the specific activity was $5.12 \mathrm{U} / \mathrm{mg}$ protein. The ammonium sulphate concentrated enzyme preparation had a protein content of $60.57 \mathrm{mg}$ with specific activity of $20.11 \mathrm{U} / \mathrm{mg}$ protein, showing purification fold of 3.92 . The enzyme recovery at this step was $6.23 \%$. The fractions collected after ammonium sulphate precipitation were loaded on the column packed with DEAE Sepharose CL-6B and fractions each containing $2 \mathrm{~mL}$ were collected and analyzed for both enzyme activity and protein content

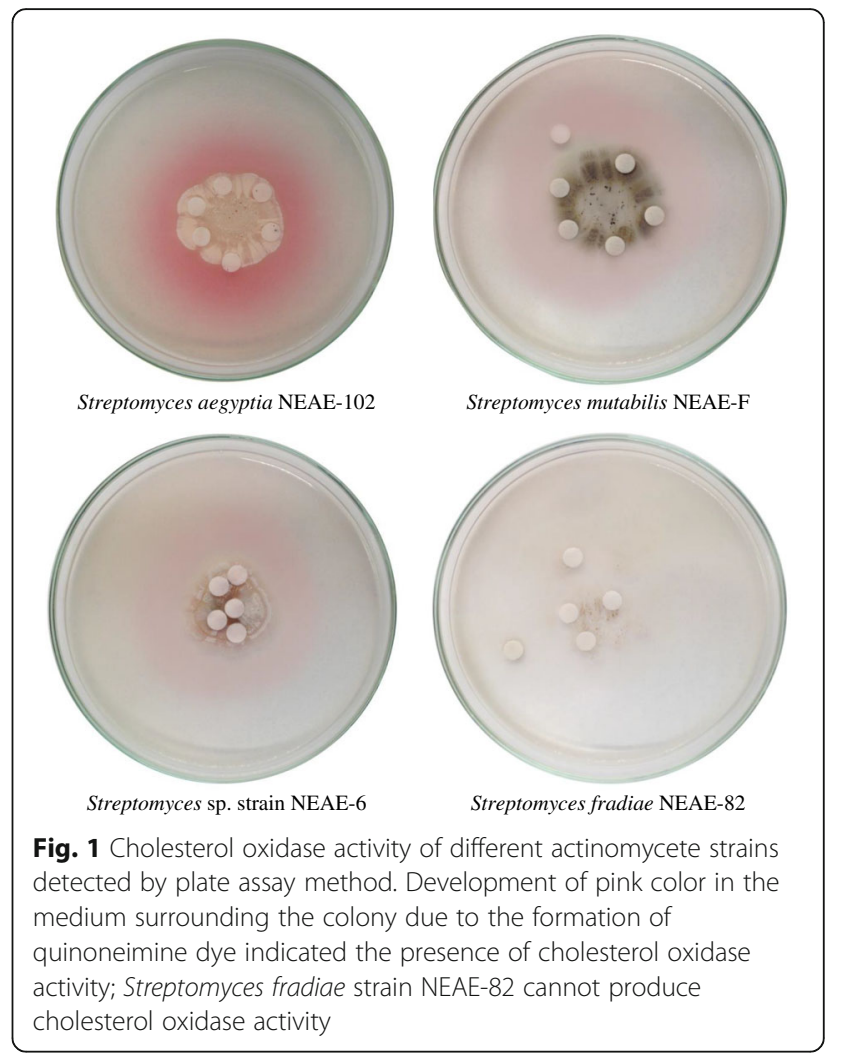

for each separate fraction. The elution pattern obtained using DEAE Sepharose was graphically illustrated in Fig. 2. A total of 150 fractions were collected that showed one major cholesterol oxidase activity peak on the chromatogram. Cholesterol oxidase was purified to homogenity after ion exchange column separation contained DEAE Sepharose CL-6B with $501.05 \mathrm{U}$ total activity and $31.15 \mathrm{mg}$ protein. The enzyme was purified with specific activity of $16.08 \mathrm{U} / \mathrm{mg}$ of protein. Summary of the purification steps of the cholesterol oxidase produced by Streptomyces aegyptia NEAE 102 is presented in Table 1.

\section{Physico-chemical characteristics of cholesterol oxidase} Cholesterol oxidases from several microorganisms from various species have been isolated, purified and characterized. The activity of cholesterol oxidase of Streptomyces aegyptia NEAE 102 was evaluated at various levels of temperature, $\mathrm{pH}$, effect of substrate concentration and incubation time.

\section{Effect of incubation time on cholesterol oxidase activity} The cholesterol oxidase activity (Fig. 3) increased as the incubation time increased up to $105 \mathrm{~min}(190.98 \mathrm{U} / \mathrm{mL})$. Time beyond $105 \mathrm{~min}$ has slight decrease the activity of the enzyme (188.49 U/mL at $120 \mathrm{~min}$ of incubation). 


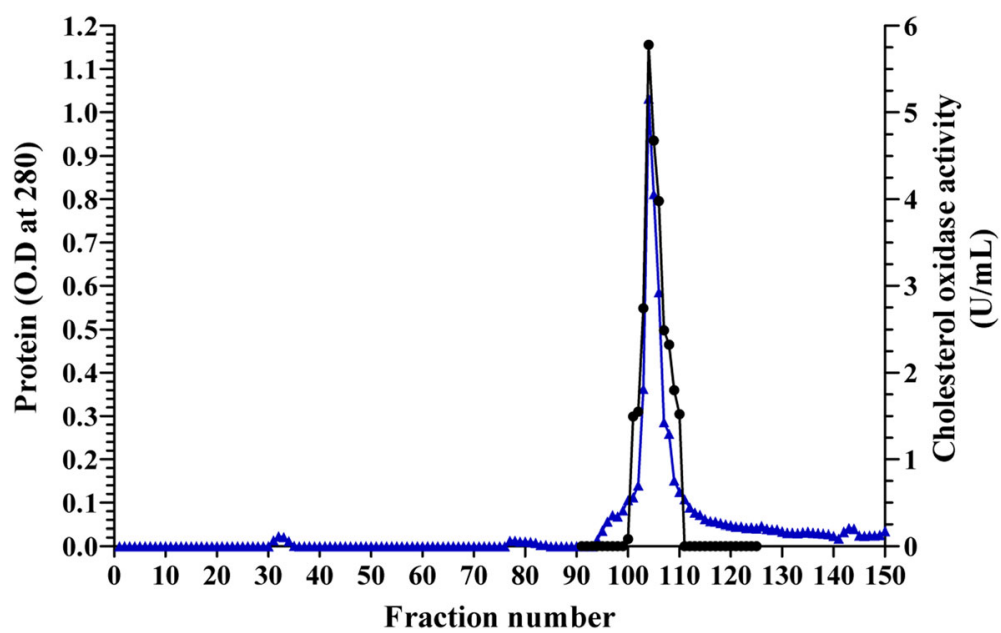

Fig. 2 Purification of cholesterol oxidase produced by Streptomyces aegyptia NEAE 102 using ion exchange on DEAE Sepharose CL-6B. ( $\mathbf{\Delta}$ ) refer to protein, $(\bullet)$ refer to cholesterol oxidase activity

\section{Effect of temperature on cholesterol oxidase activity} The temperature optimum of cholesterol oxidase from Streptomyces aegyptia NEAE 102 is shown in Fig. 4. It showed marked activity with range of temperatures between 25 and $45{ }^{\circ} \mathrm{C}$. The maximum cholesterol oxidase activity of $230.6 \mathrm{U} / \mathrm{mL}$ was obtained at $37{ }^{\circ} \mathrm{C}$ and at higher temperature the activity was declined. At temperature of $45^{\circ} \mathrm{C}$, the enzyme retained its $93.18 \%$ relative activity to the optimal activity. The enzyme retains $61.06 \%$ of its activity at $50{ }^{\circ} \mathrm{C}$. The temperature ranges of notably cholesterol oxidase activity reported from different sources were $30-70{ }^{\circ} \mathrm{C}$ $[10,21,22]$. Most cholesterol oxidases exhibit optimum temperatures for enzyme activity in the range of $50-60{ }^{\circ} \mathrm{C}$ [23]. The optimum temperature of cholesterol oxidase activity from Rhodococcus sp. GKI was found to be around $30{ }^{\circ} \mathrm{C}$. At temperature of $45{ }^{\circ} \mathrm{C}$, the enzyme retained its $92 \%$ relative activity to the optimal activity [24]. Praveen et al. [22] reported that the optimum temperature of cholesterol oxidase from Streptomyces parvus at $\mathrm{pH} 7.2$ was $50^{\circ}$ C. The cholesterol oxidase from Streptomyces fradiae is the most thermo-tolerant reported so far with optimum

Table 1 Summary of the purification steps of the cholesterol oxidase produced by Streptomyces aegyptia NEAE 102

\begin{tabular}{|c|c|c|c|c|c|}
\hline \multirow{2}{*}{$\begin{array}{l}\text { Purification } \\
\text { step }\end{array}$} & \multirow{2}{*}{$\begin{array}{l}\text { Total } \\
\text { protein } \\
\text { content } \\
\text { (mg) }\end{array}$} & \multicolumn{4}{|c|}{ Cholesterol oxidase activity } \\
\hline & & $\begin{array}{l}\text { Total } \\
\text { activity (U) }\end{array}$ & $\begin{array}{l}\text { Specific } \\
\text { activity } \\
\text { (U/mg } \\
\text { protein) }\end{array}$ & $\begin{array}{l}\text { Recovery } \\
\text { (\%) }\end{array}$ & $\begin{array}{l}\text { Purification } \\
\text { fold }\end{array}$ \\
\hline Culture filtrate & 3811.27 & 19527.53 & 5.12 & 100 & 1 \\
\hline $\begin{array}{l}\left(\mathrm{NH}_{4}\right)_{2} \mathrm{SO}_{4} \\
\text { post dialysis }\end{array}$ & 60.57 & 1217.88 & 20.11 & 6.23 & 3.92 \\
\hline $\begin{array}{l}\text { lon exchange } \\
\text { on DEAE } \\
\text { Sepharose } \\
\text { CL-6B }\end{array}$ & 31.15 & 501.05 & 16.08 & 2.56 & 3.14 \\
\hline
\end{tabular}

temperature of $70{ }^{\circ} \mathrm{C}[25]$. Optimum temperature for cholesterol oxidase activity produced by Pseudomonas aeruginosa was determined by Jasim and Diwan [26] and the results showed that the optimum temperature for enzyme activity was $35{ }^{\circ} \mathrm{C}$ when the enzyme was added to cholesterol solution and incubated at different temperatures ranged between 25 and $65{ }^{\circ} \mathrm{C}$ for $10 \mathrm{~min}$. At this temperature, the activity was $3.48 \mathrm{U} / \mathrm{mL}$, and represents the optimum for enzyme activity because of the high effect on the reaction energy for both enzyme and substrate which leads to formation of enzyme-substrate complex and this will result in increasing the reaction speed as it was mentioned by Urban et al. [27], hence enzyme activity was decreased above and below this temperature. Most enzymes are often highly sensitive to high temperatures, while others which contain disulfide bonds are more stable in high temperatures than complex enzymes with high molecular weights as it was described by Segel [28].

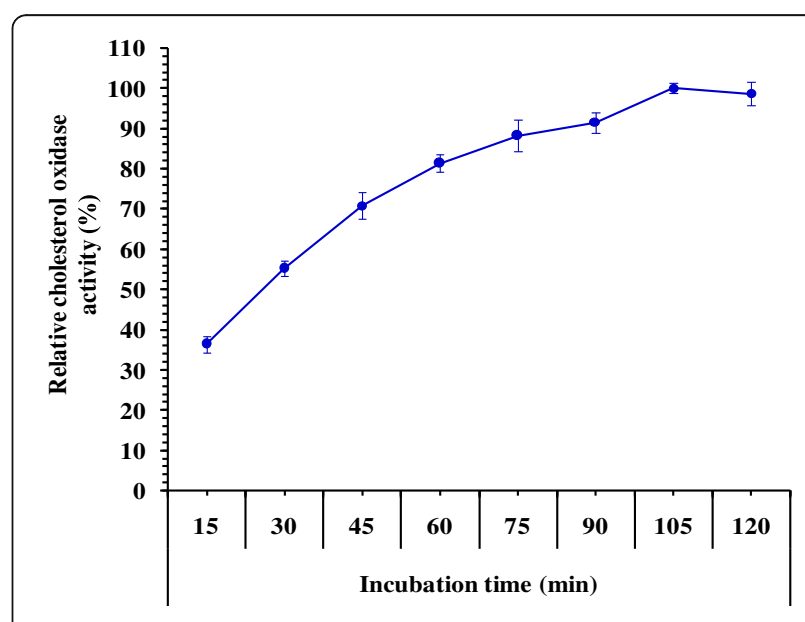

Fig. 3 Effect of different incubation periods on cholesterol oxidase 


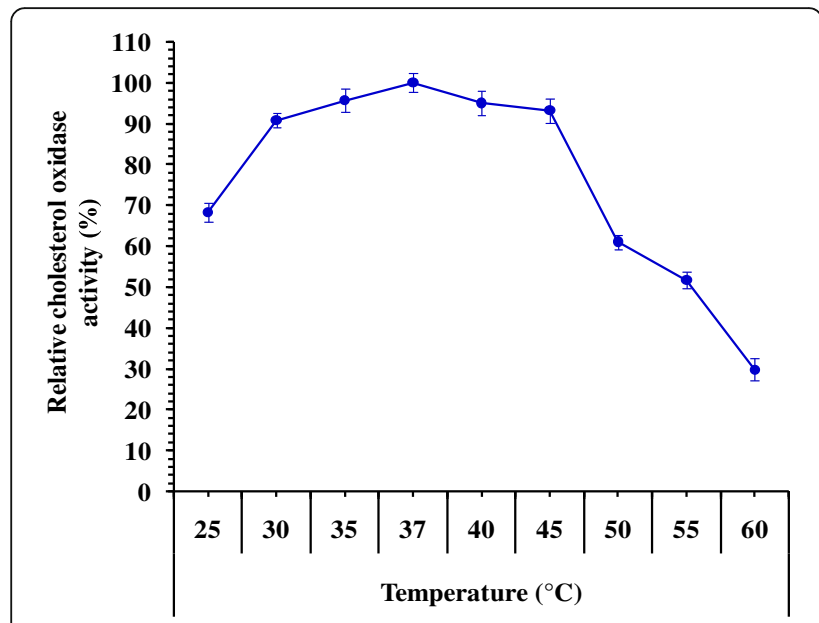

Fig. 4 Effect of the temperature on cholesterol oxidase activity

Other studies reported that the temperature of 53,47 and $40{ }^{\circ} \mathrm{C}$ were optimal for cholesterol oxidase activity from Brevibacterium sp. [29], Rhodoccocus equi and Corynebacterium cholesterolicum [30]; respectively. While Yazdi and Zahraei [25] reported optimum temperature at around $50^{\circ}$ $\mathrm{C}$ and plateau between 40 and $60{ }^{\circ} \mathrm{C}$ for the purified enzyme from Streptomyces violascens. Whereas, other authors reported that the optimum temperature for cholesterol oxidase from Bacillus sp., Arthrobacter simplex and Streptomyces violascens was found to range between 50 and $60{ }^{\circ} \mathrm{C}$ and obvious enzyme thermostability [31]. The optimum temperature for cholesterol oxidase was found to be $50{ }^{\circ} \mathrm{C}$ and it retained more than $70 \%$ activity at $50{ }^{\circ} \mathrm{C}$ after $60 \mathrm{~min}$ of heat treatment [32]. The optimal reaction temperature for cholesterol oxidase was $45^{\circ} \mathrm{C}$; it retained more than $80 \%$ activity in the temperature range $35-48{ }^{\circ} \mathrm{C}$ [33]. Comparing the effect of different temperatures on enzyme activity under a standard condition, cholesterol oxidase showed a marked activity between 20 and $50{ }^{\circ} \mathrm{C}$ with maximum activity at $35^{\circ} \mathrm{C}$ [14]. Varma and Nene [34] found that cholesterol oxidase in the clarified fermentation broth have almost full activity at $45{ }^{\circ} \mathrm{C}$ for $1 \mathrm{~h}$; at $50{ }^{\circ} \mathrm{C}$ with retained activity of $50 \%$.

\section{Effect of $\mathrm{pH}$ on cholesterol oxidase activity}

Cholesterol oxidase activity was studied as a function of $\mathrm{pH}$ in range between 4 and 10 (Fig. 5). The maximum enzyme activity at $\mathrm{pH} 7$ is $237.31 \mathrm{U} / \mathrm{mL}$ (relative activity, 100\%). At lower and higher $\mathrm{pH}$ 's, enzyme activity was decreased. The enzyme retains $99.44 \%$ of its activity at $\mathrm{pH} 8(235.99 \mathrm{U} /$ $\mathrm{mL})$. However, the enzyme retains 57.59 and $10.98 \%$ of its activity at $\mathrm{pH} 9$ and $\mathrm{pH} 5$, respectively. Cholesterol oxidases from various microbial sources generally characterized to have neutral $\mathrm{pH}$ optima around $\mathrm{pH} 7.0$ to 7.5 with stability over a wide $\mathrm{pH}$ range $[10,23]$. The cholesterol oxidase from Streptomyces parvus exhibited maximum activity at

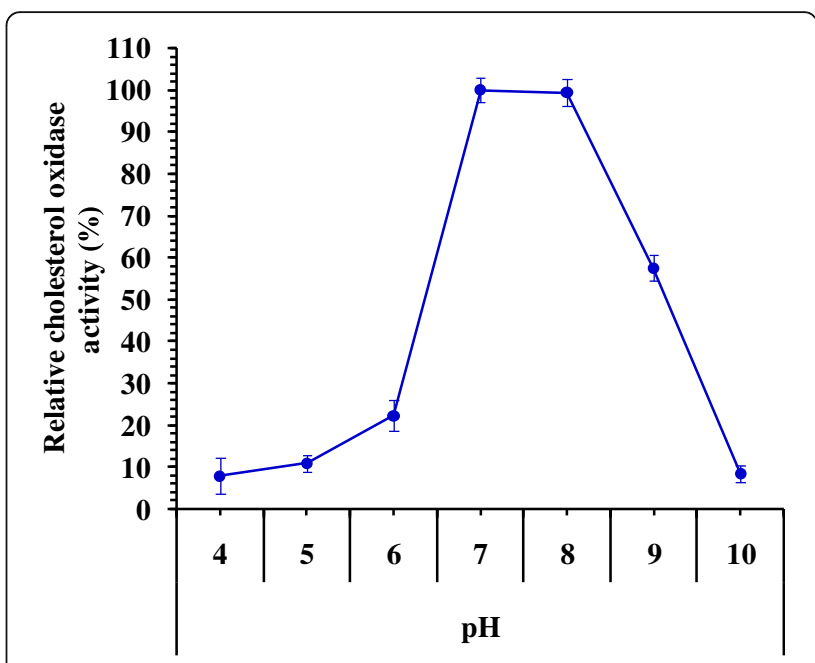

Fig. 5 Activity of cholesterol oxidase as a function of the $\mathrm{pH}$ of the reaction

$\mathrm{pH} 7.2$ [22], while $\mathrm{pH} 7.5$ was optimum for the enzyme from Brevibacterium sp. [29], that slightly decreased to $80 \%$ at $\mathrm{pH}$ range of 6.0-8.7. Jasim and Diwan [26] reported that the optimum $\mathrm{pH}$ for cholesterol oxidase activity was $\mathrm{pH}$ 7.0, when the purified enzyme was added to cholesterol solution incubated previously at a range of $\mathrm{pH}$ between 5.0 and 9.0 for $10 \mathrm{~min}$ at $32{ }^{\circ} \mathrm{C}$. At this $\mathrm{pH}$, enzyme activity was $3.8 \mathrm{U} / \mathrm{mL}$, and the activity was decreased at the acidic and basic $\mathrm{pH}$ values because of the conformational changes in enzyme configuration due to the changes in the ionizable groups located in the active sites of the enzyme as it was mentioned by Whitaker [9]. Similar result was reported for the cholesterol oxidase from Streptomyces sp. which was most active at $\mathrm{pH} 7.0$ [35]. The optimum $\mathrm{pH}$ of cholesterol oxidase reported from different sources were ranged from 5.0 to $8.5[10,21,22]$. The optimal $\mathrm{pH}$ for cholesterol oxidase was 7.5 and retained more than $80 \%$ activity in the $\mathrm{pH}$ range of 6.5-9.0 [33]. The best $\mathrm{pH}$ for cellular cholesterol oxidase enzyme produced by Rhodococcus sp. was $\mathrm{pH} 7.5$ [14]. Cholesterol oxidase is $\mathrm{pH}$ dependent with maximum activity at $\mathrm{pH}$ around 7.0. Enzyme activity was found to be stable for at least $60 \mathrm{~min}$ at $\mathrm{pH} 7.0$ by exhibiting more than $80 \%$ activity [32].

\section{Effect of substrate concentration on the activity of cholesterol oxidase}

The influence of substrate concentration on cholesterol oxidase activity was examined at different concentrations of substrate ranging from 0.05 to $0.5 \mathrm{mM}$ to determine the optimum concentration required to give the highest cholesterol oxidase activity. The results in Fig. 6 showed a gradual increase in the enzyme activity with the increase in substrate concentration from 0.05 to $0.4 \mathrm{mM}$. However, further increase in substrate concentration $(0.45$ to $0.5 \mathrm{mM}$ ) lead to decrease in enzyme activity to $93.03 \%$ with 


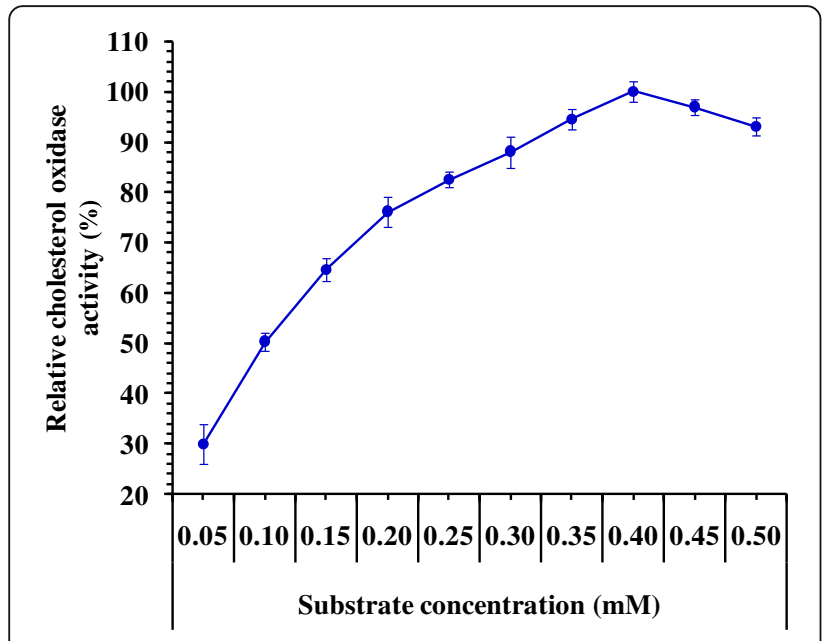

Fig. 6 Effect of the substrate concentration of the reaction on cholesterol oxidase activity

$0.5 \mathrm{mM}$ substrate. The optimum substrate concentration for maximum cholesterol oxidase activity was observed at $0.4 \mathrm{mM}(423.3 \mathrm{U} / \mathrm{mL})$.

The typical Michaelis-Menten relationship was obtained between the substrate concentrations and the initial velocity of the reaction. Michaelis-Menten plot showed in Fig. 7 illustrated the $\mathrm{K}_{\mathrm{m}}$ and $\mathrm{V}_{\max }$ values for cholesterol oxidase enzyme. The plot gave $K_{m}$ value of $0.152 \mathrm{mM}$ and $\mathrm{V}_{\max }$ of $554.6 \mathrm{U} / \mathrm{mL}$ for the hydrolysis of cholesterol. $K_{m}$ value is defined as the concentrations of substrate that permits the enzyme to achieve half of the maximum reaction rate $\left(\mathrm{V}_{\max }\right)$ which implies that half of the enzyme active sites in the sample are filled (i.e. saturated) by substrate molecules in the steady state. $K_{m}$ provides useful information regarding the affinity of the enzyme for its substrate [36]. The enzyme with a low $K_{m}$ has strong binding affinity between the enzyme and substrate. $V_{\max }$ is expressed the maximum velocity of the reaction that reveals the turn over number of an enzyme

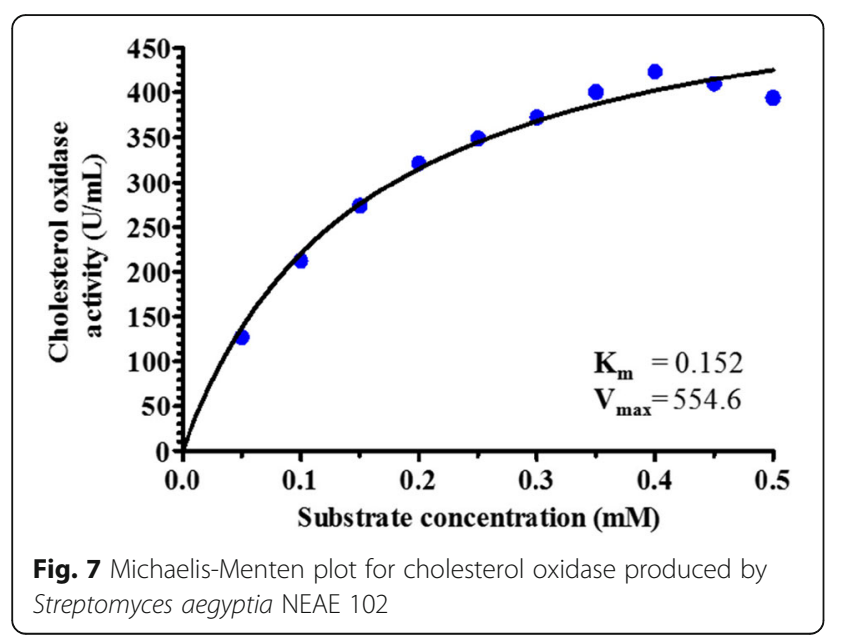

which is the number of molecules of substrate converted into product by one enzyme site per second. If the molar concentration of enzyme is known, $\mathrm{V}_{\max }$ be expressed as moles of product formed per second per mole of enzyme sites [37]. However, there are many factors that affect on kinetic parameters of the enzymes $\left(\mathrm{K}_{\mathrm{m}}\right.$ and $\left.\mathrm{V}_{\max }\right)$ such as; type of enzyme, different forms of enzyme (crude, modified or purified), changes in enzyme conditions $(\mathrm{pH}$, temperature, etc.), source of the enzyme (different microorganisms), type of used substrates and the assay procedures [38].

Doukyu et al. [39] determined the $K_{m}$ and $V_{\max }$ values of cholesterol oxidases from various bacterial origins. The $\mathrm{K}_{\mathrm{m}}$ values were 26.2, 18.4, 18.8, 76.8, 183 and $315 \mu \mathrm{M}$ from Chromobacterium sp. DS-1, Nocardia sp., N. erythropolis, B. cepacia, P. fluorescens and Streptomyces sp., respectively. Thus, the $\mathrm{K}_{\mathrm{m}}$ values of cholesterol oxidase from Streptomyces aegyptia NEAE 102 is relatively lower than those of $B$. cepacia, P. fluorescens and Streptomyces sp.

\section{Thermal stability}

The heat stability of cholesterol oxidase is of a great advantage for clinical use [31]. The effect of temperature on the stability of cholesterol oxidase showed maximum enzyme activity at $50{ }^{\circ} \mathrm{C}$ (Fig. 8). Around $63.86 \%$ of the initial activity was retained by the enzyme after incubation at $50{ }^{\circ} \mathrm{C}$ for $20 \mathrm{~min}$. Increasing exposure time up to 90 min resulted in about $43.64 \%$ of the enzyme activity, while a rapid decrease in the enzyme activity (6.68\%) was observed after incubation at $80{ }^{\circ} \mathrm{C}$ for $60 \mathrm{~min}$. Thermal inactivation process of the enzyme follows the theoretical curve of a sample first order reaction. However, linear regression of the obtained data was assayed to determine half-life time $\left(\mathrm{T}_{1 / 2}\right)$ as shown in Table 2 . The half-life time $\left(\mathrm{T}_{1 / 2}\right)$ was $156.25 \mathrm{~min}$ at $50{ }^{\circ} \mathrm{C}$, while being $107.27 \mathrm{~min}$ at $60{ }^{\circ} \mathrm{C}$. On the other hand, destruction of enzyme activity

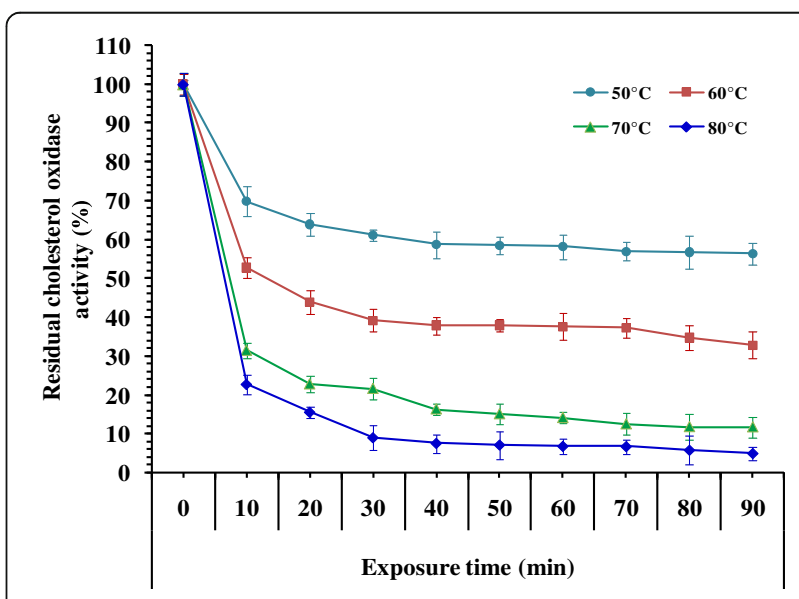

Fig. 8 Thermal stability of cholesterol oxidase as a function of the time of the reaction 
Table 2 Half life time $\left(T_{1 / 2}\right)$ and heat deactivation constant ( $k$ ) of cholesterol oxidase produced by Streptomyces aegyptia NEAE 102

\begin{tabular}{|c|c|}
\hline \multicolumn{2}{|c|}{ Half life time (min) } \\
\hline $50^{\circ} \mathrm{C}$ & 156.25 \\
\hline $60^{\circ} \mathrm{C}$ & 107.27 \\
\hline $70{ }^{\circ} \mathrm{C}$ & 81.82 \\
\hline $80^{\circ} \mathrm{C}$ & 80.33 \\
\hline \multicolumn{2}{|c|}{ Thermal inactivation rate constant $k_{d} 1\left(\min ^{-1}\right)^{a}$} \\
\hline $50^{\circ} \mathrm{C}$ & 0.0044 \\
\hline $60^{\circ} \mathrm{C}$ & 0.0065 \\
\hline $70{ }^{\circ} \mathrm{C}$ & 0.0085 \\
\hline $80^{\circ} \mathrm{C}$ & 0.0086 \\
\hline \multicolumn{2}{|c|}{ D-value (min) } \\
\hline $50^{\circ} \mathrm{C}$ & 281.25 \\
\hline $60{ }^{\circ} \mathrm{C}$ & 193.09 \\
\hline $70{ }^{\circ} \mathrm{C}$ & 147.28 \\
\hline $80^{\circ} \mathrm{C}$ & 144.60 \\
\hline \multicolumn{2}{|c|}{ Thermal inactivation rate constant $k_{d} 2\left(\min ^{-1}\right)^{b}$} \\
\hline $50^{\circ} \mathrm{C}$ & 0.0025 \\
\hline $60{ }^{\circ} \mathrm{C}$ & 0.0036 \\
\hline $70{ }^{\circ} \mathrm{C}$ & 0.0047 \\
\hline $80^{\circ} \mathrm{C}$ & 0.0048 \\
\hline
\end{tabular}

${ }^{a} k_{d} 1$ is the deactivation constant after losing $50 \%$ of initial activity (at $\mathrm{T}_{1 / 2}$ )

${ }^{\mathrm{b}} k_{d} 2$ is the deactivation constant after losing $90 \%$ of initial activity (at D-value)

was observed at $80{ }^{\circ} \mathrm{C}$ with low half-life time $(80.33 \mathrm{~min})$. It can be concluded from the previous results that the higher thermal stability behavior of cholesterol oxidase was at $50{ }^{\circ} \mathrm{C}$. Results presented in Table 2 were normalized to activity of un-incubated enzyme (time $0=100 \%$ ) for the percentage of activity remaining. Heat inactivation half-life $\left(\mathrm{T}_{1 / 2}\right)$ and heat deactivation constant $(k)$ were determined by fitting the data to a first-order decay curve using Graph-Pad Prism software.

Elalami et al. [24] reported that cholesterol oxidase from Rhodococcus sp. GKI was stable at the temperatures of 20, 30 and $40{ }^{\circ} \mathrm{C}$ for $2 \mathrm{~h}$ while, the half-life of cholesterol oxidase activity at $50{ }^{\circ} \mathrm{C}$ was around $70 \mathrm{~min}$. Cholesterol oxidase obtained from Rhodococcus sp. R14-2 retained its maximum activity for $30 \mathrm{~min}$ at $50{ }^{\circ} \mathrm{C}$ but at temperatures higher than $60{ }^{\circ} \mathrm{C}$, enzyme significantly inhibit its activity and at $70{ }^{\circ} \mathrm{C}$ was exhibited no activity within $1 \mathrm{~h}$ [21]. A highly thermostable cholesterol oxidase has been reported from Chromobacterium sp. strain DS-1 in comparison to the cholesterol oxidases obtained from various microbial sources of diverse environments such as Nocardia sp., Pseudomonas fluorescens, Streptomyces sp., Nocardia erythropolis, Cellulomonas sp. and B. cepacia ST-200 [39]. Similar result was reported for all of these commercial enzymes which suppress most of their activity after incubation at $60-80{ }^{\circ} \mathrm{C}$ for $30 \mathrm{~min}[39,40]$. Praveen et al. [22] reported that cholesterol oxidase from
Streptomyces parvus did not lose its activity from 4 to $65{ }^{\circ} \mathrm{C}$ and exhibit optimum activity at temperature $50{ }^{\circ} \mathrm{C}$ with a pH value of 7.2. However, activity comparison after incubation for $30 \mathrm{~min}$ at 55,60 and $65{ }^{\circ} \mathrm{C}$ showed retained activity about 68,66 and 46\%, respectively and lost almost all activity (86\%) after $30 \mathrm{~min}$ at $75^{\circ} \mathrm{C}$.

Cholesterol oxidase of Streptomyces virginiae showed marked stability below $40{ }^{\circ} \mathrm{C}$ without notable inactivation after incubation of the enzyme for $6 \mathrm{~h}$. However, cholesterol oxidase activity rapidly declined at temperature exceeded $50{ }^{\circ} \mathrm{C}$ with retained activity of approximately 40 and $17 \%$ of its initial activity after incubation for $6 \mathrm{~h}$ at $50^{\circ} \mathrm{C}$ and $1 \mathrm{~h}$ at $60{ }^{\circ} \mathrm{C}$, respectively [33]. The commercially available cholesterol oxidases from different microbial sources such as Streptomyces sp., Pseudomonas fluorescens, Cellulomonas sp., B. cepacia ST-200, Nocardia erythropolis and Nocardia sp.[41] exhibit complete lose of their activity after incubation at $60-80{ }^{\circ} \mathrm{C}$ for $30 \mathrm{~min}[39,40]$. But, the enzyme from Streptomyces aegyptia NEAE 102 retained $39.16 \%$ of its original activity at $60^{\circ} \mathrm{C}$ after $30 \mathrm{~min}$.

A multiple mutant (R135H, S103T andV121A) showed the highest half life stability of $52.2 \mathrm{~min}$ at $60{ }^{\circ} \mathrm{C}$ compared to wild type which had half life stability of $7.8 \mathrm{~min}$ [41]. The optimum stability of cholesterol oxidase produced from Streptomyces fradiae is reported at $70{ }^{\circ} \mathrm{C}$ with complete retained activity at $50{ }^{\circ} \mathrm{C}$ for $90 \mathrm{~min}$ [25]. Moreover, almost full enzyme activity was observed at temperatures up to $40{ }^{\circ} \mathrm{C}$ and $\mathrm{pH} 7.5$ for $1 \mathrm{~h}$. However, the enzyme retained up to 65 and $50 \%$ of its activity at temperatures of $45-50{ }^{\circ} \mathrm{C}$ for $30 \mathrm{~min}$ and $1 \mathrm{~h}$, and only $20 \%$ of the enzyme was active for $30 \mathrm{~min}$ at $55{ }^{\circ} \mathrm{C}$ [34]. Cholesterol oxidase of Pseudomonas sp. showed stability at temperatures from 4 to $50{ }^{\circ} \mathrm{C}$. However about $73 \%$ of its activity was retained after the incubation at $60{ }^{\circ} \mathrm{C}$, and almost complete loss of activity at $70{ }^{\circ} \mathrm{C}$ [42].

\section{The storage life of cholesterol oxidase enzyme}

The effect of different storage periods on the stability of cholesterol oxidase are shown in Table 3. Around 71.65\%

Table 3 The storage life of cholesterol oxidase produced by Streptomyces aegyptia NEAE 102

\begin{tabular}{lll}
\hline $\begin{array}{l}\text { Storage period } \\
\text { (Day) }\end{array}$ & \multicolumn{2}{l}{ Residual cholesterol oxidase activity (\%) } \\
\cline { 2 - 3 } 0 & At $4^{\circ} \mathrm{C}$ & At room temperature \\
\hline 0 & 100 & 100 \\
1 & 95.19 & 49.78 \\
2 & 85.06 & 32.48 \\
3 & 80.00 & 27.90 \\
4 & 78.99 & 23.66 \\
5 & 77.97 & 18.30 \\
6 & 74.18 & 17.86 \\
7 & 71.65 & 17.41 \\
\hline
\end{tabular}


of the initial activity was retained by the enzyme after 7 days of storage at $4{ }^{\circ} \mathrm{C}$, while a rapid decrease in the enzyme activity (17.41\%) was observed after storage at room temperature for the same period of time (7 days). Cholesterol oxidase enzyme from S. lavendulae NCIM 2421 kept in a sterile container at room temperature had a storage life of 5 days and full retained enzyme activity when stored at $4{ }^{\circ} \mathrm{C}$ for 60 days with half-life of 105 days [34]. However, cholesterol oxidase enzyme from S. parvus had storage life of 6 months at $4{ }^{\circ} \mathrm{C}[22]$.

\section{pH stability}

The effect of $\mathrm{pH}$ on the stability of cholesterol oxidase exhibited optimum enzyme activity at $\mathrm{pH} 7$ (Fig. 9). At this $\mathrm{pH}$, the enzyme activity was more stable, the remaining activity was 86.96 and $54.48 \%$ after $3 \mathrm{~h}$ and $24 \mathrm{~h}$. Slight decrease was observed by increasing $\mathrm{pH}$ up to 9 for $3 \mathrm{~h}$ (83.31\%). At $\mathrm{pH}$ 5, the enzyme retained $82.36 \%$ of its activity after $3 \mathrm{~h}$ and losing most of its activity $(15.95 \%)$ after $24 \mathrm{~h}$.

The cholesterol oxidase from Streptomyces sp. had an optimum $\mathrm{pH}$ for enzyme activity at $\mathrm{pH} 7.0$ and $80 \%$ of its activity was retained at $\mathrm{pH}$ 6-8 for $24 \mathrm{~h}$, but activity rapidly declined at higher or lower $\mathrm{pH}$, and at $\mathrm{pH} 10$, only $10.16 \%$ of its activity was retained [35]. On the other hand, it was found that the optimum $\mathrm{pH}$ for the stability of cholesterol oxidase produced by Pseudomonas aeruginosa was $\mathrm{pH} 6.5$. At this $\mathrm{pH}$, the enzyme activity was $3.62 \mathrm{U} / \mathrm{mL}$, and the remaining activity was $100 \%$ [26]. The cholesterol oxidase from Streptomyces parvus had optimum activity at $\mathrm{pH} 7.2$ and exhibited activity stability within a broad $\mathrm{pH}$ range of 4.0-11. However $40 \%$ of its activity was lost at pH 11 for $30 \mathrm{~min}$ [22]. Comparable $\mathrm{pH}$ stability was also reported by Varma and Nene [34] in which cholesterol oxidase showed stable activity values in the $\mathrm{pH}$ range of $6-10$ for $1 \mathrm{~h}$ at $30{ }^{\circ} \mathrm{C}$, but it lost $60 \%$ of its activity below

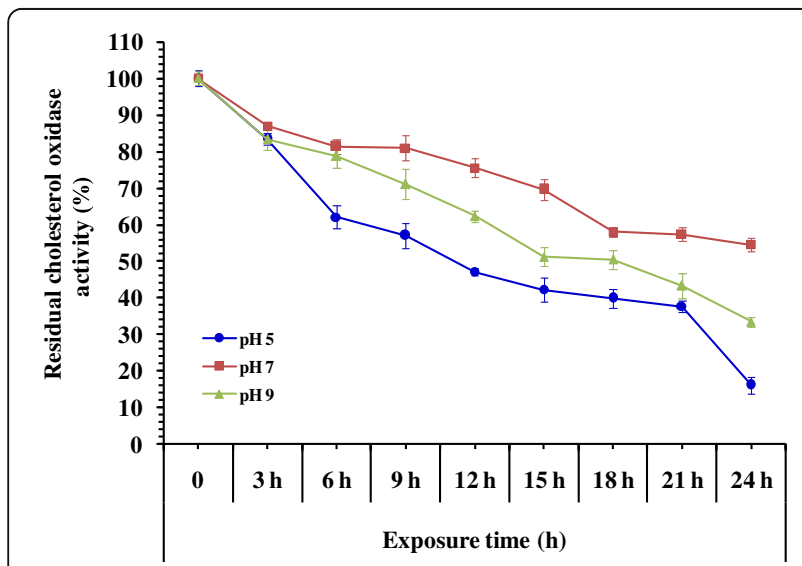

Fig. $9 \mathrm{pH}$ stability of cholesterol oxidase as a function of the time of the reaction
$\mathrm{pH} 4$ and above $\mathrm{pH}$ 10. A further declination of activity (11-17\%) was reported in the range of $\mathrm{pH} 5-8$ after incubation at $4{ }^{\circ} \mathrm{C}$ for $24 \mathrm{~h}$ and $60 \%$ of the activity was retained above this range. At $\mathrm{pH} 4$ the enzyme was almost completely inhibited. Cholesterol oxidase from Streptomyces fradiae [25] was stable in the $\mathrm{pH}$ range 410 at $4{ }^{\circ} \mathrm{C}$ for $4 \mathrm{~h}$.

\section{Molecular weight determination by Sodium Dodecyl Sulphate- Polyacrylamide Gel Electrophoresis}

The molecular weight of the purified cholesterol oxidase released from the final purification step on DEAE Sepharose was determined by SDS-PAGE according to the method of Laemmli [20]. The electrophoretic mobilities versus logarithmus of molecular weights of standard proteins (molecular mass range: $9-178 \mathrm{kDa}$ ) were photographed in Fig. 10. SDS-PAGE of the enzyme preparation revealed only a single distinctive protein band for the pure preparation of cholesterol oxidase with an apparent molecular weight of $46 \mathrm{kDa}$ (Fig. 10). The molecular weights of the cholesterol oxidases have been reported in the range of 47-61 $\mathrm{kDa}$ [10]. Two novel extracellular cholesterol oxidases designated $\mathrm{CO} 1$ and $\mathrm{CO} 2$, from

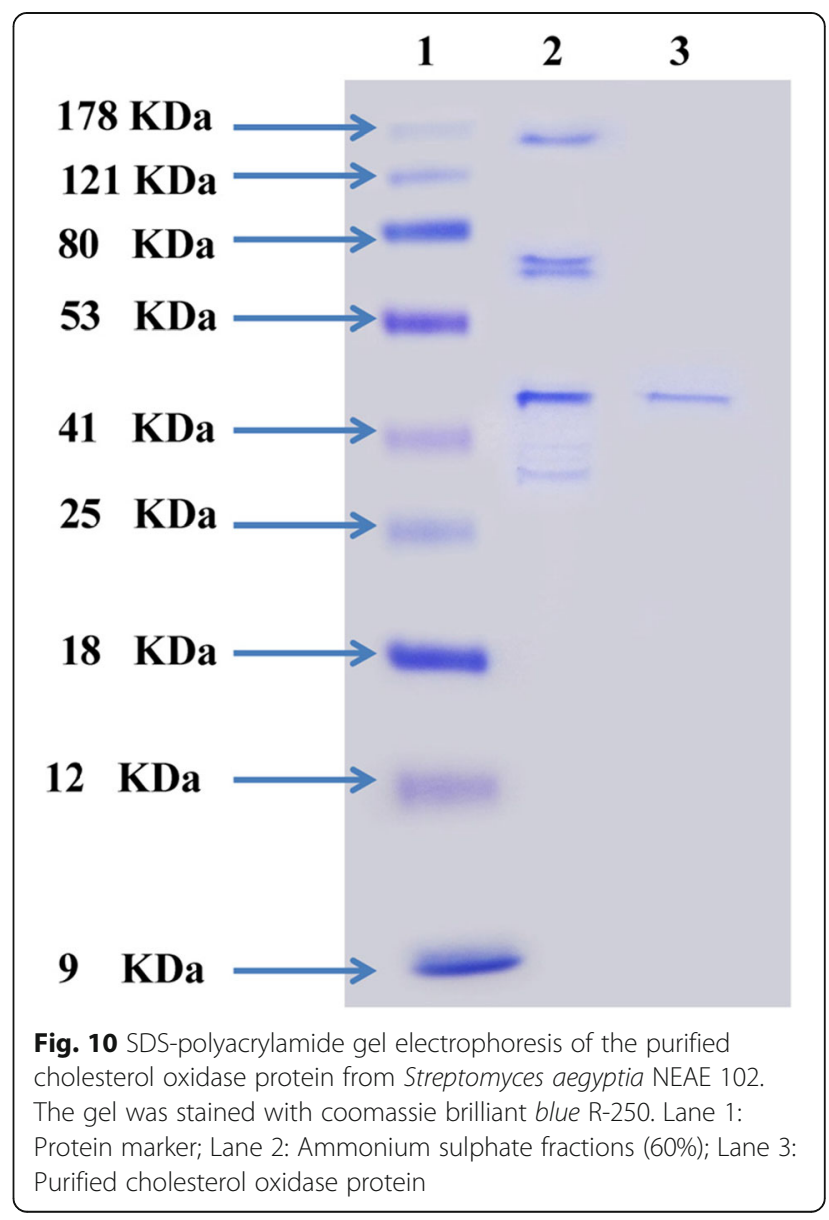


Bacillus sp. SFF34, were purified giving molecular weights values of 36 and $37 \mathrm{kDa}$ [11]. The molecular weight of the obtained cholesterol oxidase was concluded to be $20.1 \mathrm{kDa}$ [32].

\section{Amino acid composition}

Table 4 and Fig. 11 shows the amino acid contents of the purified cholesterol oxidase produced by Streptomyces aegyptia NEAE 102. Glutamic acid was the most represented amino acid in the quantified cholesterol oxidase $(11.49 \mu \mathrm{g} / \mathrm{mL})$. Relatively higher amounts of leucine, arginine, alanine were present. There are 20 commonly occurring amino acids in proteins which are found either in the free state or as linear chains in peptides and proteins. Amino acid analysis has an important role in the study of the composition of proteins, foods and feedstuffs. Free amino acids are also determined in biological material, such as plasma and urine, and in fruit juice and wine. When it is performed on a pure protein, amino acid analysis is capable of identifying the protein and the analysis is also used as a prerequisite for Edman degradation and mass spectrometry and to determine the most suitable enzymatic or chemical digestion method for further study of the protein. It is also a useful method for quantitating the amount of protein in a sample and can give more accurate results than colorimetric methods [43].

\section{Conclusions}

Different actinomycete strains were screened for their cholesterol oxidase activity using plate method. The promising isolate, Streptomyces aegyptia NEAE 102 was selected for further studies. The crude enzyme extract was purified using ammonium sulfate precipitation,

Table 4 Amino acids content of purified cholesterol oxidase produced by Streptomyces aegyptia NEAE 102

\begin{tabular}{|c|c|c|c|c|c|}
\hline \multirow[t]{2}{*}{ Amino acid } & \multicolumn{4}{|c|}{ Residue concentration } & \multirow{2}{*}{$\begin{array}{l}\text { Estimated no. of residues } / \mathrm{mol}^{\mathrm{a}} \\
\text { (to nearest integer) }\end{array}$} \\
\hline & $\mu \mathrm{g} / \mathrm{ml}$ & $\mathrm{nmol} / \mathrm{ml}$ & $\mathrm{g} / \mathrm{mol}$ & Mol.\% & \\
\hline \multicolumn{6}{|l|}{ Hydrophobic } \\
\hline \multicolumn{6}{|l|}{ Aliphatic } \\
\hline Glycine (Gly) & 5.53 & 73.71 & 75.06 & 10.76 & 39 \\
\hline Alanine (Ala) & 7.77 & 87.26 & 89.09 & 12.73 & 46 \\
\hline Isoleucine (Ile) & 3.46 & 26.40 & 131.17 & 3.85 & 14 \\
\hline Leucine (Leu) & 10.28 & 78.71 & 130.67 & 11.49 & 42 \\
\hline Valine (Val) & 3.66 & 31.21 & 117.14 & 4.55 & 16 \\
\hline \multicolumn{6}{|l|}{ Aromatic } \\
\hline Phenylalanine (Phe) & 5.71 & 34.54 & 165.17 & 5.04 & 18 \\
\hline \multicolumn{6}{|l|}{ Charged } \\
\hline \multicolumn{6}{|l|}{ Acidic } \\
\hline Aspartic acid (Asp + Asn) & 5.62 & 42.24 & 133.00 & 6.16 & 22 \\
\hline Glutamic acid (Glu + Gln) & 11.49 & 78.12 & 147.11 & 11.40 & 41 \\
\hline \multicolumn{6}{|l|}{ Basic } \\
\hline Histidine (His) & 5.91 & 38.10 & 155.17 & 5.56 & 20 \\
\hline Lysine (Lys) & 5.48 & 37.46 & 146.18 & 5.47 & 20 \\
\hline Arginine (Arg) & 8.67 & 49.79 & 174.19 & 7.27 & 26 \\
\hline \multicolumn{6}{|l|}{ Polar } \\
\hline Serine (Ser) & 4.31 & 40.96 & 105.10 & 5.98 & 22 \\
\hline Threonine (Thr) & 5.27 & 44.26 & 119.11 & 6.46 & 23 \\
\hline Methionine (Met) & 0.33 & 2.21 & 148.42 & 0.32 & 1 \\
\hline \multicolumn{6}{|l|}{ Aromatic } \\
\hline Tyrosine (Tyr) & 3.67 & 20.28 & 181.16 & 2.96 & 11 \\
\hline Total & & & & & 361 \\
\hline
\end{tabular}

${ }^{a}$ The number of calculated amino acid based on: if the MW of the purified enzyme is $46000 \mathrm{Da}$ and average MW of the 20 most common aa is 110 Da, the no. of aa will be approximately $46000 / 110=418$ aa. Trp-residues cannot be determined, based on the methodology used. Pro residues were also not detectable. Because of the deletion of 2 of the 20 amino acids in the calculation: W, P (=10\%), we have taken away $10 \%$ of aa 

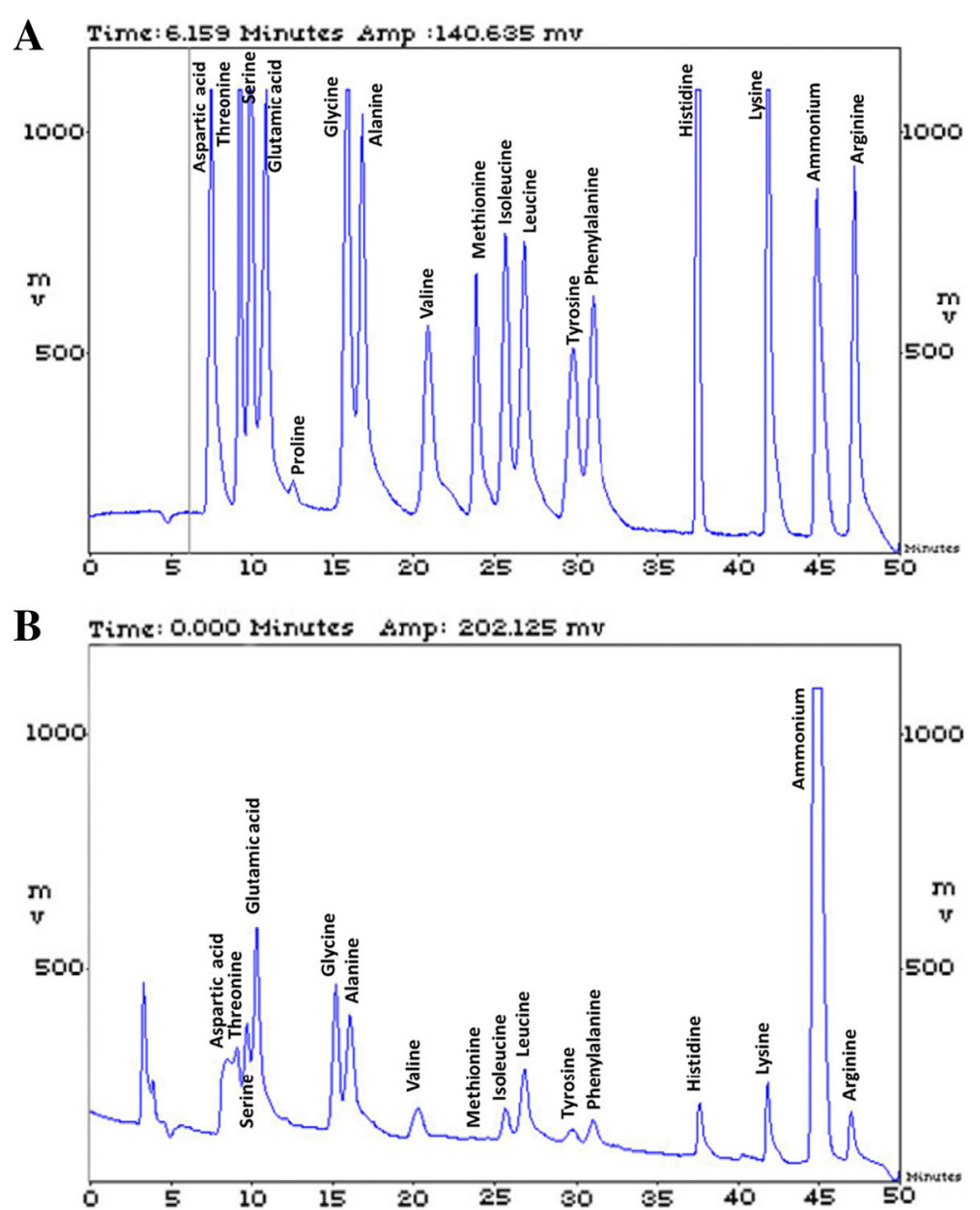

Fig. 11 a Chromatogram of the amino acid standard mixture; $\mathbf{b}$ the chromatogram of Streptomyces aegyptia NEAE 102 cholesterol oxidase

dialysis and ion exchange chromatography using DEAE Sepharose CL-6B. The enzyme was purified 3.14-fold and showed a final specific activity of $16.085 \mathrm{U} / \mathrm{mg}$ protein. The molecular weight of the purified cholesterol oxidase was determined as $46 \mathrm{KDa}$. Glutamic acid was the most represented amino acid in the quantified cholesterol oxidase $(11.492 \mu \mathrm{g} / \mathrm{mL})$.

\section{Abbreviations}

FAD: Flavin adenine dinucleotide; $k$ : Heat deactivation constant; KDa: Kilodalton; $\mathrm{K}_{\mathrm{m}}$ : Michaelis-Menten constant; SDS-PAGE: Sodium dodecyl sulfatepolyacrylamide gel electrophoresis; $T_{1 / 2}$ : Half-life time; $V_{\max }$ : Maximal velocity

\section{Acknowledgments}

This work was supported by City of Scientific Research and Technological Applications, Alexandria, Egypt.

\section{Funding}

None

Availability of data and materials Not applicable

\section{Authors' contributions}

NEE proposed the research concept, designed the experiments, providing necessary tools for experiments, experimental instructions, conducted most of the experiments, analyzed and interpreted the data, wrote the manuscript and final approval of the manuscript. SFD designed and conducted some of the experiments, provided some instruments, experimental instructions, as well as contributed to reviewing process. HMS assisted in some scientific experiments, contributed to the manuscript reviewing and had given final approval of the version to be published. NME participate in the revision of the manuscript. NME carried out the experiments. All authors read and approved the final manuscript.

\section{Competing interests}

The authors declare that they have no competing interests.

Consent for publication

Not applicable

Ethics approval and consent to participate Not applicable

\section{Publisher's note}

Springer Nature remains neutral with regard to jurisdictional claims in published maps and institutional affiliations. 


\section{Author details}

'Department of Bioprocess Development, Genetic Engineering and Biotechnology Research Institute, City of Scientific Research and Technological Applications, Alexandria, Egypt. ${ }^{2}$ Department of Protein Research, Genetic Engineering and Biotechnology Research Institute, City of Scientific Research \& Technological Applications, Alexandria, Egypt. ${ }^{3}$ Department of Botany, Faculty of Science, Mansoura University, Mansoura, Egypt. ${ }^{4}$ Biopharmacetical Product Research Department, Genetic Engineering and Biotechnology Research Institute, City of Scientific Research and Technological Applications, Alexandria, Egypt.

Received: 24 December 2016 Accepted: 21 March 2017 Published online: 29 March 2017

\section{References}

1. MacLachlan J, Wotherspoon ATL, Ansell RO, Brooks CJW. Cholesterol oxidase:sources, physical properties and analytical applications. J Steroid Biochem Mol Biol. 2000;72:169-95.

2. Corbin DR, Greenplate JT, Wong EY, Purcell JP. Cloning of an insecticidal cholesterol oxidase gene and its expression in bacteria and plant protoplasts. Appl Environ Microbiol. 1994;12:4239-44.

3. Purcell JP, Greenplate JT, Jennings MG. Cholesterol oxidase: a potent insecticidal protein active against Boll weevil larvae. Biochem Biophys Res Commun. 1993;196:1406-13.

4. Watanabe K, Shimizu H, Aihara H, Nakamura R, Suzuki Kl, Momagata K. Isolation and identification of cholesterol degradation Rhodococcus strains food of animal origin and their cholesterol oxidase activities. J Gen Appl Microbiol. 1986;32:137-47.

5. Sampson NS, Vrielink A. Cholesterol oxidases: a study of nature's approach to protein design. Acc Chem Res. 2003;36:713-22.

6. Vrielink A, Ghisla S. Cholesterol oxidase: biochemistry and structural features. FEBS J. 2009;276:6826-43.

7. Pollegioni L, Gadda G, Ambrosius D, Ghisla S, Pilone MS. Cholesterol oxidase from Streptomyces hygroscopicus and Brevibacterium sterolicum: effect of surfactants and organic solvents on activity. Biotechnol Appl Biochem. 1999;30:27-33.

8. Lee MT, Chen WC, Chou CC. Medium improvement by orthogonal array designs for cholesterol oxidase production by Rhodococcus equi No. 23. Process Biochem. 1997;32:697-703.

9. Whitaker JR. Principles of enzymology for the food science. New York: Marcel Dekker; 1972.

10. Doukyu N. Characteristics and biotechnological applications of microbial cholesterol oxidases. Appl Microbiol Biotechnol. 2009;83:825-37.

11. Rhee $\mathrm{CH}$, Kim KP, Park HD. Two novel extracellular cholesterol oxidases of Bacillus sp. isolated from fermented flatfish. Biotechnol Lett. 2002;24:1385-9.

12. El-Naggar NE, Sherief AA, Hamza SS. Streptomyces aegyptia sp. Nov., a novel cellulolytic streptomycete isolated from soil in Egypt. Afr J Microbiol Res. 2011;29:5308-15.

13. Waksman SA. The actinomycetes. Classification, identification and description of genera and species. Baltimore: Williams and Wilkins Company; 1961.

14. Lashkarian H, Raheb J, Shahzamani K, Hossein S, Shamsara M. Extracellular cholesterol oxidase from Rhodococcus sp. isolation and molecular characterization. Iran Biomed J. 2010;2:49-57.

15. Yazdi MT, Kamranpour N, Zahraei M, Agaiepour K. Streptomyces fradiae, a Potent Producer of Cholesterol Oxidase. Iran J Sci Technol Trans. 1999;3:151-7.

16. Sasaki I, Goto H, Yamamoto R, Tanaka H, Takami Kl, Yamashita K, Horio T. Hydrophobic ionic chromatography: its application to microbial glucose oxidase, hyaluronidase, cholesterol oxidase and cholesterol esterase. J Biochem. 1982;5:1555-61.

17. Lowry OH, Rosebrough NJ, Farr AL, Randall RJ. Protein measurement with the Folin phenol reagent. J Boil Chem. 1951;1:265-75.

18. Lineweaver $\mathrm{H}$, Burk $\mathrm{D}$. The determination of enzyme dissociation constants. J Am Chem Soc. 1934;3:658-66.

19. Stone MM, Weiss MS, Goodale CL, Adams MB, Fernandez IJ, German DP, Allison SD. Temperature sensitivity of soil enzyme kinetics under Nfertilization in two temperate forests. Glob Chang Biol. 2012;3:1173-84.

20. Laemmli UK. Cleavage of structural proteins during the assembly of the head of bacteriophage T4. Nature. 1970;227:680-5.

21. Wang C, Cao Y, Sun B, Ji B, Nout MJR, Wang J, Zhao Y. Preparation and some properties of cholesterol oxidase from Rhodococcus sp. R14-2. World J Microbiol Biotechnol. 2008;24:2149-57.
22. Praveen V, Srivastava A, Tripathi CKM. Purification and characterization of the enzyme cholesterol oxidase from a new isolate of Streptomyces sp. Appl Biochem Biotechnol. 2011;165:1414-26.

23. Nishiya Y, Harada N, Teshima S, Yamashita M, Fujii I, Hirayama N, Murooka Y. Improvement of thermal stability of Streptomyces cholesterol oxidase by random mutagenesis and a structural interpretation. Protein Eng. 1997;10:231-5.

24. Elalami A, Kreit J, Filali MA, Bourdrant J, Germain P. Characterization of a secreted cholesterol oxidase from Rhodococcus sp. GK1. World J Microbiol Biotechnol. 1999;15:579-85.

25. Yazdi MT, Zahraei M, Aghaepour K, Kamranpour N. Purification and partial characterization of a cholesterol oxidase from Streptomyces fradiae. World J Microbiol Biotechnol. 2001;8:410-4.

26. Jasim HM, Diwan SY. Isolation and identification of cholesterol oxidase producing Pseudomonas aeruginosa. Iraqi J Sci. 2010;2:284-9.

27. Urban A, Martina L, Thoreston E, Erichjaeger K. DsbA and DsbC effect extracellular enzyme formation in Pseudomonas aeruginosa. J Bacteriol. 2001;2:587-96.

28. Segel IH. Biochemical calculations. 2nd ed. New York: Wiley; 1976.

29. Tomioka H, Kagawa M, Nakamura S. Some enzymatic properties of $3 \beta$ hydroxysteroid oxidase produced by Streptomyces violascens. J Biochem. 1976;5:903-15.

30. De Martinez S, Green C. The action of cholesterol oxidases on cholesterol in vesicles and micelles. Biochem Soc Trans. 1979:5:978-9.

31. Kumari L, Kanwar SS. Cholesterol oxidase and its applications. Adv Microbiol. 2012;2:49-65.

32. Palani P, Rajesh KG, Florentyna R. Isolation, extraction and partial purification of cholesterol oxidase from Stenotrophomonas sp. Int J Pharm Technol. 2014;6(1):6355-66.

33. Li B, Wang W, Wang FQ, Wei DZ. Cholesterol oxidase ChoL is a critical enzyme that catalyzes the conversion of diosgenin to 4-ene-3-keto steroids in Streptomyces virginiae IBL-14. Appl Microbiol Biotechnol. 2010;85:1831-8.

34. Varma R, Nene S. Biosynthesis of cholesterol oxidase by Streptomyces lavendulae NCIM 2421. Enzyme Microb Technol. 2003;33:286-91.

35. Niwas R, Singh V, Singh R, Tripathi D, Tripathi CKM. Production, purification and characterization of cholesterol oxidase from a newly isolated Streptomyces sp. World J Microbiol Biotechnol. 2013;29:2077-85.

36. Wulff $\mathrm{G}$. Enzyme-like catalysis by molecularly imprinted polymers. Chem Rev. 2002;1:1-28.

37. Bisswanger H. Multiple equilibria. Enzyme kinetics: principles and methods. 2002. p. 5-50.

38. Copeland RA. Enzymes: a practical introduction to structure, mechanism, and data analysis. New York: Wiley; 1997.

39. Doukyu N, Shibata K, Ogino H, Sagermann M. Purification and characterization of Chromobacterium sp. DS1 cholesterol oxidase with thermal, organic solvent, and detergent tolerance. Appl Microbiol Biotechnol. 2008;80:59-70.

40. Doukyu N, Aono R. Cloning, sequence analysis and expression of a gene encoding an organic solvent and detergent tolerant cholesterol oxidase of Burkholderia cepacia strain ST 200. Appl Microbiol Biotechnol. 2001;57:146-52.

41. Doukyu N, Shibata K, Ogino H, Sagermann M. Cloning, sequence analysis and expression of a gene encoding Chromobacterium sp. DS1 cholesterol oxidase. Appl Microbiol Biotechnol. 2009;82:479-90.

42. Aono R, Doukyu N. Purification of extracellular cholesterol oxidase with high activity in the presence of organic solvents from Pseudomonas sp. strain ST200. Appl Environ Microbiol. 1998;64:1929-32.

43. Cooper GM, Hausman RE. The cell sunderland: sinauer associates. 2000. p. 725-30.

\section{Submit your next manuscript to BioMed Central and we will help you at every step:}

- We accept pre-submission inquiries

- Our selector tool helps you to find the most relevant journal

- We provide round the clock customer support

- Convenient online submission

- Thorough peer review

- Inclusion in PubMed and all major indexing services

- Maximum visibility for your research

Submit your manuscript at www.biomedcentral.com/submit 